\title{
Correction: Male contraception: where are we going and where have we been?
}

Reynolds-Wright JJ, Anderson RA. Male contraception: where are we going and where have we been? BMJ Sex Reprod Health 2019;45:236-42.

There is a minor error in the paper. At present the text incorrectly reads: 'While the trial was stopped early by a WHO review panel due to concern over side effects (despite very few men discontinuing treatment), there were just four pregnancies, giving a contraceptive efficacy of $1.59 \%$ (CI 0.6 to 4.2 ), ${ }^{12}$ thus matching hormonal female methods and substantially better than condoms, the only current reversible male method.'

The correct text should be: 'While the trial was stopped early by a WHO review panel due to concern over side effects (despite very few men discontinuing treatment), there were just four pregnancies, giving a Pearl index of 2.18 pregnancies per 100 person-years (95\% CI, 0.82 to 5.80), ${ }^{12}$ thus matching hormonal female methods and substantially better than condoms, the only current reversible male method.

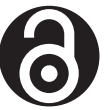

OPEN ACCESS

Open access This is an open access article distributed in accordance with the Creative Commons Attribution 4.0 Unported (CC BY 4.0) license, which permits others to copy, redistribute, remix, transform and build upon this work for any purpose, provided the original work is properly cited, a link to the licence is given, and indication of whether changes were made. See: https:// creativecommons.org/licenses/by/4.0/.

(C) Author(s) (or their employer(s)) 2020. Re-use permitted under CC BY. Published by BMJ.

BMJ Sex Reprod Health 2020;46:157. doi:10.1136/bmjsrh-2019-200395corr1

Check for updates 